\title{
Geoheritage and Geotourism Resources
}

\author{
Nicoletta Santangelo $(D$ and Ettore Valente * \\ Department of Earth, Environmental and Resources Sciences, University of Naples Federico II, via Cinthia 21, \\ 80126 Naples, Italy; nicsanta@unina.it \\ * Correspondence: ettore.valente@unina.it
}

Received: 22 June 2020; Accepted: 26 June 2020; Published: 28 June 2020

\begin{abstract}
This Special Issue wants to outline the role of Geoheritage and Geotourism as potential touristic resources of a region. The term "Geoheritage" refers to a peculiar type of natural resources represented by sites of special geological significance, rarity or beauty that are representative of a region and of its geological history, events and processes. These sites are also known as "geosites" and, as well as archaeological, architectonic and historical ones, they can be considered as part of the cultural estate of a country. "Geotourism" is an emerging type of sustainable tourism, which concentrates on geosites, furnishing to visitors knowledge, environmental education and amusement. In this meaning, Geotourism may be very useful for geological Sciences divulgation and may furnish additional opportunities for the development of rural areas, generally not included among the main touristic attractions. The collected papers focused on these main topics with different methods and approaches and can be grouped as follows: (i) papers dealing with geosites promotion and valorisation in protected areas; (ii) papers dealing with geosites promotion and valorisation in non-protected areas; (iii) papers dealing with geosites promotion by exhibition, remote sensing analysis and apps; (iv) papers investigating geotourism and geoheritage from the tourists' perspective.
\end{abstract}

Keywords: geoheritage; geotourism; geosite; geomorphosite; geoitinerary; geological science divulgation

\section{Editorial for the Special Issue Geoheritage and Geotourism Resources}

The Earth, the planet we live on, can be seen as a dynamic mixture of water and rocks forming the landscape we look at and we walk on every day. It is usual to admire landscapes in different parts of the world, which means in areas with a different climate and different geological history, that may inspire a sense of wonder and that let the people to travel for very long distances to be in touch with these amazing portions of the globe. Typical examples are the Yellowstone National Park and the Niagara Falls in the USA, the Iguazu Falls in South America, the fjords in Scandinavia, the Vesuvius in Italy, the Hymalaya in Asia, the Sahara Desert in Africa and the Ayers Rock in Australia. These fascinating rock outcrops and landforms are an example of the so-called Geoheritage [1-3]. They are places (generally named geosites/geomorphosites) where the processes responsible for Earth's dynamic and evolution are so well represented that they may be considered as temples or open air museum to explain the history of our planet. The concept of Geoheritage find its full application in the context of protected areas and of Geoparks in particular, but there many geosites/geomorphosites widespread all over the world and they are not always included in protected areas. Rocks and landforms may be used to divulge the knowledge of Earth's history to a wide audience and not only to experts, thus acting as a resource not only from an economic point of view [4]. To use the rocks and the landforms as a resource, their scientific, educational and touristic values, among all, must be defined thus enhancing their role as geosites and geomorphosites [5-10]. Once the role of either a geosite or a geomorphosite as a potential geotouristic attraction is established, a Geotourism plan may be diffused.

The Geotourism [11] is a double-faced concept because the suffix Geo may be interpreted either as Geological or Geographical [12]. A tentative to pass over the dualism between the Geological and 
the Geographical approach to Geotourism has been proposed by the Arouca Declaration [13]. The Geological and the Geographical approaches to Geotourism may be seen as two working ideas that run parallel each other, such as they are never meeting each other in analysis. In contrast, they are complementary, and their combination may provide a comprehensive analysis of the Geotourism potential of some areas, showing what nature offers to humans and how humans are able to manage nature in a sustainable way.

\section{The Special Issue}

The main aim of this Special Issue is to outline the role of Geoheritage and Geotourism as potential tools for touristic development and educational activity, especially for geological sciences divulgation. In this Special Issue we have collected 14 papers dealing with Geoheritage and Geotourism in Europe (moreover in Italy, seven papers; Poland, three papers; Malta, one paper; Iceland, one paper; and Czech Republic, one paper) and South America (in Ecuador, one paper). Both the Geological and Geographical approaches to Geotourism are present in the papers published in the Special Issue (Table 1), with study areas that comprehend both portions of Geoparks and areas not included in a Geopark.

Table 1. List of papers published in the Special Issue grouped according to the type of approach, the main aim and the contents.

\begin{tabular}{|c|c|c|c|}
\hline Paper & $\begin{array}{l}\text { Approach to } \\
\text { Geotourism }\end{array}$ & Main Aims/Geographic Context & Contents \\
\hline $\begin{array}{l}\text { - Valente et al. [14]; } \\
\text { - Perotti et al. [15]; } \\
\text { - Santangelo et al. [16]; }\end{array}$ & Geological & $\begin{array}{l}\text { - Promotion of Geoheritage and } \\
\text { Geotourism } \\
\text { - Educational purposes } \\
\text { - Areas already included in Natural } \\
\text { park or Geopark }\end{array}$ & $\begin{array}{l}\text { - Proposal of a geo-itinerary and 3D models } \\
\text { (Valente et al. [14]); } \\
\text { - Proposal of fieldtrips and virtual tours } \\
\text { (Perotti et al. [15]); } \\
\text { - Proposal of a geoitinerary with educational } \\
\text { purposes (Santangelo et al. [16]); }\end{array}$ \\
\hline $\begin{array}{l}\text { - Melelli, [22]; } \\
\text { - Pasquarè-Mariotto et al. [23]; } \\
\text { - Filocamo et al. [24] }\end{array}$ & Geological & $\begin{array}{l}\text { - Promotion of Geoheritage and } \\
\text { Geotourism by exhibition, remote } \\
\text { sensing analysis and apps } \\
\text { - Areas not included in a Geopark }\end{array}$ & $\begin{array}{l}\text { - Proposal of a multimedia exhibition } \\
\text { (Melelli, [22]); } \\
\text { - Field photos, UAV images and 3D models } \\
\text { (Pasquarè-Mariotto et al. [23]); } \\
\text { - Creation of an app for electronic devices } \\
\text { (Filocamo et al. [24]) }\end{array}$ \\
\hline $\begin{array}{l}\text { - Rozenkiewicz et al. [25]; } \\
\text { - Widawski et al. [26]; } \\
\text { - Zgłobicki et al. [27]; }\end{array}$ & Geographical & $\begin{array}{l}\text { - Investigate Geotourism and } \\
\text { Geoheritage from the tourists' } \\
\text { perspective }\end{array}$ & $\begin{array}{l}\text { - Online information availability on } \\
\text { georesources (Rozenkiewicz et al. [25]); } \\
\text { - Opinion of weekend tourists } \\
\text { (Widawski et al. [26]) } \\
\text { - Geosite assessments and questionnaire to } \\
\text { tourists (Zgłobicki et al. [27]); }\end{array}$ \\
\hline
\end{tabular}

The general approach includes geosites/geomorphosites identification and evaluation by means of several methodologies [5-10]. This step is generally followed by the proposition of geo-itineraries that, in the case of areas already included in protected areas [14-16,26], aims at implementing the valorizations of the sites and at focusing on their potential didactic/touristic values. In particular, Perotti et al. [15] explained how different methods and approaches (fieldtrips and virtual tours together with more traditional ones like explicative panels and in situ museum) helped in outlining the geodiversity of the Valsesia Geopark. Widawsky et al. [26] instead analyzed the tourist potential in terms of Geotourism of the Gorczański National Park in Poland. They focused on tourist trails and 
didactic routes already existing in the park and investigated the tourists' opinion on the geotourist attractiveness of the Park. Given the peculiar park location near urbanized areas, the Authors suggested it as an attractive field for research on weekend tourism development.

Most of the other papers deals with territories that are not included in protected areas [17-21,27] presenting studies that aim at promoting Geotourism and/or at assess the Geotourism potential of these areas.

Selmi et al. [19] presented a quantitative assessment of geosites and geomorphosites in the island of Malta, in central Mediterranean Sea, showing the links existing between Geoheritage and other values of the sites (natural and cultural). One of the aim of the paper is collecting data useful for the local authorities in promoting a sustainable and responsible tourism development.

Kubalikova [20] carried out the assessment of the Geotourism potential of two areas in Southern Moravia located outside of protected areas and not far from a big city. This paper stresses how these areas can be considered as important resource for local and regional development.

Piacentini et al. [17] focused on a mountain area of the Apennines (central Italy) combining different types of cultural tourism, such as the archaeological and the geological ones. They proposed an integrated geological-archeological itinerary called the "Fan of the Terre Peligne", with the aim of enhancing the natural and cultural heritage of a poorly visited area of the inner Apennines.

There are two papers dealing with the characterization and valorization of one geosite $[18,21]$. The case of Monte del Diavolo [18] in Southern Italy is a proposal of valorizations of a site with archaeological, cultural and natural value that has been unexploited, notwithstanding the remarkable touristic flow along the nearby coastline. The case of El Sexmo gold mine [21] in Ecuador aims at highlighting the mining identity of Ecuador and to promote this site within the "Ruta del Oro" (Gold Route) Geopark project. The Authors demonstrated that the valorisation of this site will boost tourism, knowledge, and economic activity, favoring the sustainable development of Geotourism. Zgłobicki et al. [27] analysed the potential for Geotourism development in the Central Roztocze region (SE Poland) with the aim of demonstrating the importance of including this area in the proposed Geopark "Stone Forest in Roztocze". Collecting both data on geosites and tourists' opinions, the Authors demonstrate a high potential for Geotourism and consistency between scientific assessments and ratings from tourists. Despite that, the idea of geopark and Geotourism development is not supported by the state yet, whether institutionally or financially.

The paper from Rozenkiewicz et al. [25] faces the problem of Geotourism from a different point of view with respect to all the other papers. It considers the online information availability on georesources, presented on the official websites of the National Tourism Organizations (NTOs) of the Czech Republic, Poland and Slovakia. Unfortunately, the Authors found out that the information on Geotourism resources available online is rather dispersed and outlined the need of performing coordinate actions to solve this problem.

We finally want to highlight some papers [22-24] that introduce new, original and interesting approaches in the valorization of geoheritage at different levels. These papers deal with the utility of new visualization techniques as well as of devoted mobile applications in the promotion and popularization of geosites. Pasquarè Mariotto et al. [23] choose an iconic place for the geology of our planet, Iceland, to show how the main volcano-tectonic geosites may be explained and illustrated through 3D models derived from field photographs and unmanned aerial vehicle (UAV)-captured images. These models are also an example of interactive, navigable Virtual Outcrops, which are also available online. This kind of approach is surely interesting and novel and may serve as an example on how to promote Geoheritage online to reach a wide audience, with special reference to the younger generation. It could be a suggestion for all the promoters of protected areas to add to their websites' virtual reconstructions of single geosites/geomorphosites or virtual tours to catch the curiosity of a wider audience and increase the number of tourists.

Filocamo et al. [24] have implemented a mobile devise application for the Molise region, in central Italy, with the aim of helping the promotion of sustainable and eco-friendly tourism development 
in rural and inner areas of the Apennine. This application, called MoGeo App, aims at providing diversified Geotourism information that combines geologic attractions (geosites and geologic itineraries) with other possible tourist attractions (other sites of natural and cultural interest), to reach an audience as wide as possible and to respond to different interests and needs.

The paper of Melelli [22] is a unique and interesting example of Geotourism developed in an urban area, which is the city of Perugia (Umbria, central Italy). Panels, interactive tools, laboratories inside a museum and trekking tours outside allowed the tourists to come close to Geological science as well as favored the increase of visitors in a few months, with important consequences in terms of visibility and financial return. This paper, together with those of Valente et al. [14] and Santangelo et al. [16] belong to the group of papers dedicated to explaining the educational role of Geotourism in the divulgation of Geological sciences. These studies outline the idea that the improvement of geological knowledge is a basic resource for the social and economic development of any community. Instead, increasing the sensitivity of citizens regarding the environmental estate and in the awareness of natural disasters, are fundamental steps for territorial planning policies, aiming at controlling and mitigating the risks associated with natural disasters.

Author Contributions: All authors contributed equally to writing this editorial. All authors have read and agreed to the published version of the manuscript.

Funding: This research received no external funding.

Acknowledgments: We thank our informants and supporting staff for their contribution to the Special Issue.

Conflicts of Interest: The authors declare no conflict of interest.

\section{References}

1. Newsome, D.; Dowling, R. Geoheritage and geotourism. In Geoheritage. Assessment, Protection, and Management; Reynard, E., Brilha, J., Eds.; Elsevier: Amsterdam, The Netherlands, 2018; pp. 305-321. [CrossRef]

2. Reynard, E.; Brilha, J. Geoheritage: A Multidisciplinary and Applied Research Topic. In Geoheritage. Assessment, Protection, and Management; Reynard, E., Brilha, J., Eds.; Elsevier: Amsterdam, The Netherlands, 2018; pp. 3-9. [CrossRef]

3. Brilha, J. Geoheritage and geoparks. In Geoheritage. Assessment, Protection, and Management; Reynard, E., Brilha, J., Eds.; Elsevier: Amsterdam, The Netherlands, 2018; pp. 323-334. [CrossRef]

4. Bruschi, V.M.; Coratza, P. Geoheritage and environmental impact assessment (eia). In Geoheritage. Assessment, Protection, and Management; Reynard, E., Brilha, J., Eds.; Elsevier: Amsterdam, The Netherlands, 2018; pp. 251-264. [CrossRef]

5. Pereira, P.; Pereira, D.; Caetano Alves, M.I. Geomorphosite assessment in Montesinho Natural Park (Portugal). Geogr. Helv. 2007, 62, 159-168. [CrossRef]

6. Reynard, E.; Fontana, G.; Kozlik, L.; Scapozza, C. A method for assessing the scientific and additional values of geomorphosites. Geogr. Helv. 2007, 62, 148-158. [CrossRef]

7. Vujiciić, M.D.; Vasiljevi'c, D.A.; Markovi'c, S.B.; Hose, T.A.; Luki’c, T.; Hadži'c, O.; Jani'cevi'c, S. Preliminary geosite assessment model (GAM) and its application on Fruška Gora Mountain, potential Geotourism destination of Serbia. Acta Geogr. Slov. 2011, 51, 361-376. [CrossRef]

8. Kubalíková, L. Geomorphosite assessment for geotourism purposes. Czech J. Tour. 2013, 2, 80-104. [CrossRef]

9. Brilha, J. Inventory and Quantitative Assessment of Geosites and Geodiversity Sites: A Review. Geoheritage 2016, 8, 119-134. [CrossRef]

10. Mucivuna, V.C.; Reynard, E.; Garcia, M.D.G.M. Geomorphosites Assessment Methods: Comparative Analysis and Typology. Geoheritage 2019, 11, 1799-1815. [CrossRef]

11. Ólafsdóttir, R.; Tverijonaite, E. Geotourism: A Systematic Literature Review. Geosciences 2018, 8, 234. [CrossRef]

12. Dowling, R.; Newsome, D. Geotourism: Definition, characteristics and international perspectives. In Handbook of Geotourism; Dowling, R., Newsome, D., Eds.; Edward Elgar: Cheltenham, UK, 2018; pp. 1-22. 
13. The Arouca Declaration. Available online: http://www.unesco.org/new/fileadmin/MULTIMEDIA/HQ/SC/ pdf/Geopark_Arouca_Declaration_EGN_2012.pdf (accessed on 12 June 2020).

14. Valente, E.; Santo, A.; Guida, D.; Santangelo, N. Geotourism in the Cilento, Vallo di Diano and Alburni UNESCO Global Geopark (Southern Italy): The Middle Bussento Karst System. Resources 2020, 9, 52. [CrossRef]

15. Perotti, L.; Bollati, I.M.; Viani, C.; Zanoletti, E.; Caironi, V.; Pelfini, M.; Giardino, M. Fieldtrips and Virtual Tours as Geotourism Resources: Examples from the Sesia Val Grande UNESCO Global Geopark (NW Italy). Resources 2020, 9, 63. [CrossRef]

16. Santangelo, N.; Amato, V.; Ascione, A.; Russo Ermolli, E.; Valente, E. GEOTOURISM as a Tool for Learning: A Geoitinerary in the Cilento, Vallo di Diano and Alburni Geopark (Southern Italy). Resources 2020, 9, 67. [CrossRef]

17. Piacentini, T.; Somma, M.C.; Antonelli, S.; Buccolini, M.; Esposito, G.; Mancinelli, V.; Miccadei, E. The "Fan of the Terre Peligne": Integrated Enhancement and Valorization of the Archeological and Geological Heritage of an Inner-Mountain Area (Abruzzo, Central Apennines, Italy). Resources 2019, 8, 118. [CrossRef]

18. Sansò, P. Devil Landforms as Resources for Geotourism Development: An Example from Southern Apulia (Italy). Resources 2019, 8, 131. [CrossRef]

19. Selmi, L.; Coratza, P.; Gauci, R.; Soldati, M. Geoheritage as a Tool for Environmental Management: A Case Study in Northern Malta (Central Mediterranean Sea). Resources 2019, 8, 168. [CrossRef]

20. Kubalíková, L. Assessing Geotourism Resources on a Local Level: A Case Study from Southern Moravia (Czech Republic). Resources 2019, 8, 150. [CrossRef]

21. Carrión-Mero, P.; Loor-Oporto, O.; Andrade-Ríos, H.; Herrera-Franco, G.; Morante-Carballo, F.; Jaya-Montalvo, M.; Aguilar-Aguilar, M.; Torres-Peña, K.; Berrezueta, E. Quantitative and Qualitative Assessment of the "El Sexmo" Tourist Gold Mine (Zaruma, Ecuador) as A Geosite and Mining Site. Resources 2020, 9, 28. [CrossRef]

22. Melelli, L. "Perugia Upside-Down": A Multimedia Exhibition in Umbria (Central Italy) for Improving Geoheritage and Geotourism in Urban Areas. Resources 2019, 8, 148. [CrossRef]

23. Pasquaré Mariotto, F.; Bonali, F.L.; Venturini, C. Iceland, an Open-Air Museum for Geoheritage and Earth Science Communication Purposes. Resources 2020, 9, 14. [CrossRef]

24. Filocamo, F.; Di Paola, G.; Mastrobuono, L.; Rosskopf, C.M. MoGeo, a Mobile Application to Promote Geotourism in Molise Region (Southern Italy). Resources 2020, 9, 31. [CrossRef]

25. Rozenkiewicz, A.; Widawski, K.; Jary, Z. Geotourism and the 21st Century-NTOs' Website Information Availability on Geotourism Resources in Selected Central European Countries: International Perspective. Resources 2020, 9, 4. [CrossRef]

26. Widawski, K.; Oleśniewicz, P.; Rozenkiewicz, A.; Zaręba, A.; Jandová, S. Protected Areas: Geotourist Attractiveness for Weekend Tourists Based on the Example of Gorczański National Park in Poland. Resources 2020, 9, 35. [CrossRef]

27. Zgłobicki, W.; Kukiełka, S.; Baran-Zgłobicka, B. Regional Geotourist Resources-Assessment and Management (A Case Study in SE Poland). Resources 2020, 9, 18. [CrossRef]

(C) 2020 by the authors. Licensee MDPI, Basel, Switzerland. This article is an open access article distributed under the terms and conditions of the Creative Commons Attribution (CC BY) license (http://creativecommons.org/licenses/by/4.0/). 